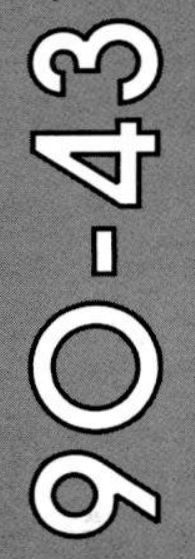

\title{
Ice Jam Analysis at Idaho Falls, Snake River, Idaho
}

Jon E. Zufelt, Jeff A. Earickson and Lester Cunningham

December 1990

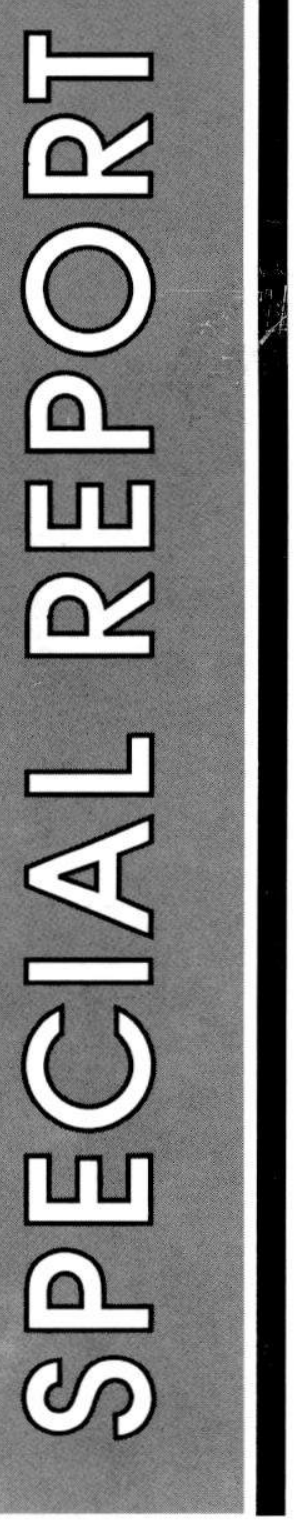




\section{Special Report 90-43}

\section{U.S. Army Corps}

of Engineers

Cold Regions Research \& Engineering Laboratory

\section{Ice Jam Analysis at Idaho Falls, Snake River, Idaho}

Jon E. Zufelt, Jeff A. Earickson and Lester Cunningham 


\section{PREFACE}

This report was prepared by Jon E. Zufelt, Research Hydraulic Engineer, of the Ice Engineering Research Branch, Experimental Engineering Division, U.S. Army Cold Regions Research and Engineering Laboratory, Jeff A. Earickson, formerly of CRREL, and Lester Cunningham, Hydraulic Engineer, Hydraulics Branch, U.S. Army Engineer District, Walla Walla. Funding was provided by USAED, Walla Walla, reimbursable work order E85860071, Analysis of Snake River Ice Conditions and Associated Flooding Upstream of the City of Idaho Falls.

The authors thank David Deck, Kate Axelson, and James Wuebben of CRREL for their valuable comments and technical review of the report. They also thank Gordon Gooch of CRREL and the City of Idaho Falls for assistance in field data collection.

The contents of this report are not to be used for advertising or promotional purposes. Citation of brand names does not constitute an official endorsement or approval of the use of such commercial products. 


\section{CONTENTS}

Preface

Introduction

The ice jam problem

Cause of ice jams in the study area

History of river ice problems

History of the Upper Power Project

Hydraulic and meteorological information

Air temperature and freezing-degree days

Snake River winter discharge data

Field measurements of water level and ice thickness

Hydraulic analysis

Calibration of the hydraulic model

Open-water computations

Ice-cover computations

Summary of computations

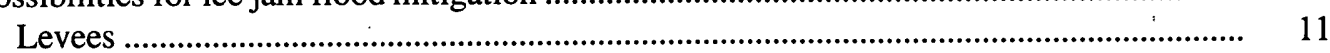

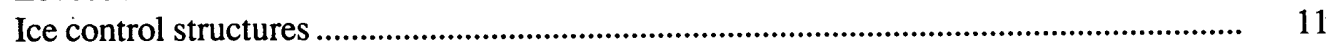

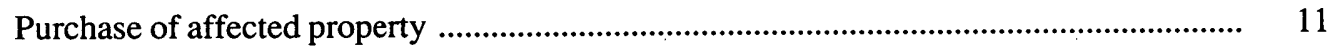

Palisades Dam flow control to promote ice cover growth ........................................... 11

Palisades Dam flow control during flood emergencies ............................................... 12

Gate operations at the Upper Power Project ............................................................ 12

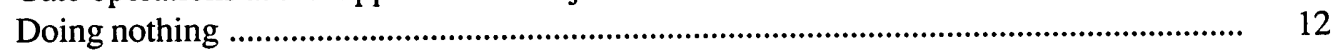

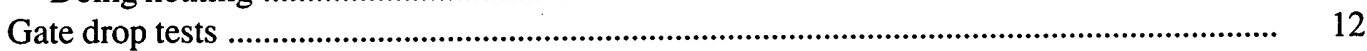

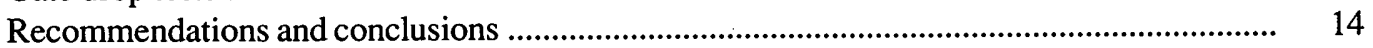

Literature cited ............................................................................................................. 15

Appendix A: History of the Upper Power Project and Vertical Survey Datums ................... 17

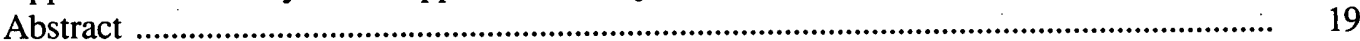

\section{ILLUSTRATIONS}

Figure

1. Location and study area maps of Snake River, Idaho .......................................... 2

2. Study reach showing cross-section locations and river miles ................................... 3

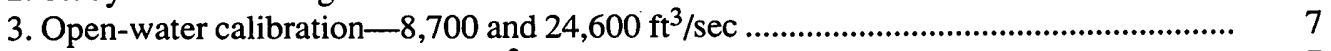

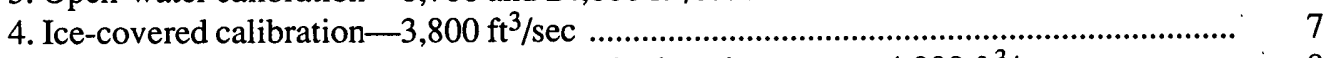

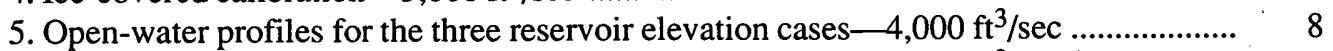

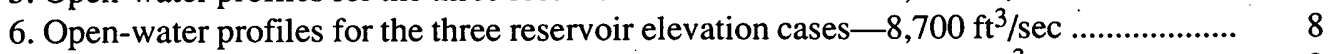

7. Open-water profiles for the three reservoir elevation cases $-24,600 \mathrm{ft}^{3} / \mathrm{sec} \ldots \ldots \ldots \ldots \ldots . . . . . \quad 8$

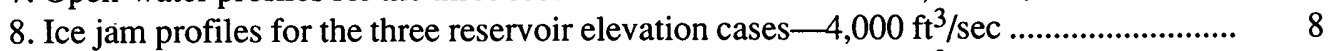

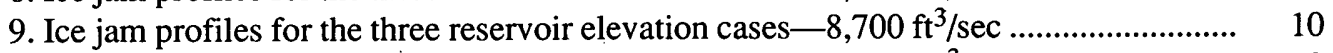

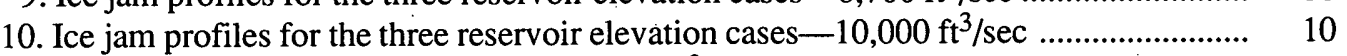

11. Ice jam profile for present project at $10,000 \mathrm{ft}^{3} / \mathrm{sec}$ showing approximate bank elevations

12. Ice jam profile for present project at $4,000 \mathrm{ft}^{3} / \mathrm{sec}$, showing observed water surface prior to gate drop tests 


\section{TABLES}

Table

1. Monthly mean discharge, Snake River at Shelley ......................................................... 5

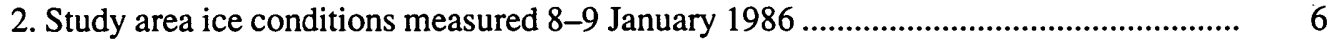

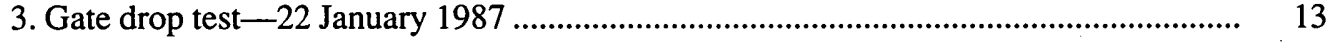




\title{
Ice Jam Analysis at Idaho Falls, Snake River, Idaho
}

\author{
JON E. ZUFELT, JEFF A. EARICKSON AND LESTER CUNNINGHAM
}

\section{INTRODUCTION}

The City of Idaho Falls, Idaho, generates hydroelectric power from three projects that the city constructed on the Snake River between river mile (RM) 794 and 800.6. The dam and power plant now located at RM 800.6, 4 miles upstream from the city, was constructed in 1982 and is referred to as the Upper Power Project (Fig. 1). A hydropower facility also existed at the Upper Power Project site from 1928 to 1971 . That facility consisted of a gated control dam (known as Dam 1) in the east channel of the river and a powerhouse in a second gated dam in the west channel of the river (Dam 2). By 1971, the gates and piers of Dam 1 had deteriorated such that a steady pool could not be held, and so the city removed several of the dam control gates and lowered the reservoir. Additional gates were removed in 1976 . Electricity continued to be generated from the power plant at Dam 2 after 1971 in a run-of-river mode when the river flow was sufficient to operate the turbines. In 1982, the remaining structures of the original project were removed and replaced with gated weirs. Dam 1 continues to operate as a control dam with a new powerhouse and weir at Dam 2. During the mid-1970s a housing development was built along the west bank of the river at a site known as Bear Island (RM 806.1-807.1), also shown in Figure 1.

Freeze-up ice jam floods on the Snake River affected the Bear Island homeowners during the winters of 19821983 to 1984-1985. Ice jam floods also threatened two houses on the west bank at RM 803 during these winters. The Bear Island homeowners associated their flooding problems with the rebuilt dams located six miles downstream. The affected. homeowners lodged complaints with the City of Idaho Falls, the Federal Energy Regula- tory Commission (FERC), and elected officials. The City of Idaho Falls requested the assistance of the U.S. Army Corps of Engineers to determine the cause of the ice jams upstream of the Upper Power Project, and to ascertain the validity of the homeowners' complaints.

In October 1985 the city commissioned the Corps of Engineers, Walla Walla District, which in turn requested the assistance of CRREL, to study the problem. Specifically, the city requested the following technical information:

1. The causes of ice jams between the Upper Power Project dams and the Idaho Canal Diversion Structure at the upstream end of Bear Island (Fig. 1).

2. How ice jams in the study area have been affected by water levels behind the present dams (1982present), behind the original dams (1928-1971), and during the interim period (1971-1982).

3 . Whether the present dams have caused or aggravated ice jam flood problems upstream, specifically at the Bear Island housing development.

4. Recommendations on alternative plans for flood control and damage mitigation.

This report describes the cause of ice jams in the study area and gives a history of river ice conditions. The results of both open-water and ice-covered hydraulic analyses of the study reach are presented. The analysis quantifies how changing reservoir levels since 1928 have affected ice jam flood levels in the area and answers the question as to whether the present dams affect Bear Island. The report also discusses flood mitigation alternatives and recommends future courses of action. Finally, the report discusses actions taken by the City of Idaho Falls and describes the results of a dam gate drop test and how these results compare with the hydraulic analyses. 


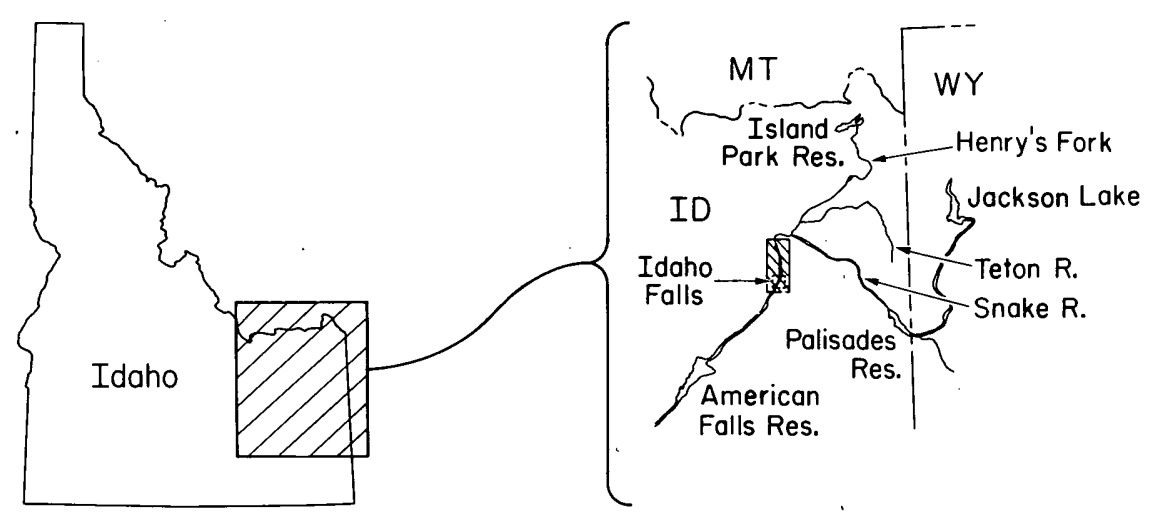

a. Location map.

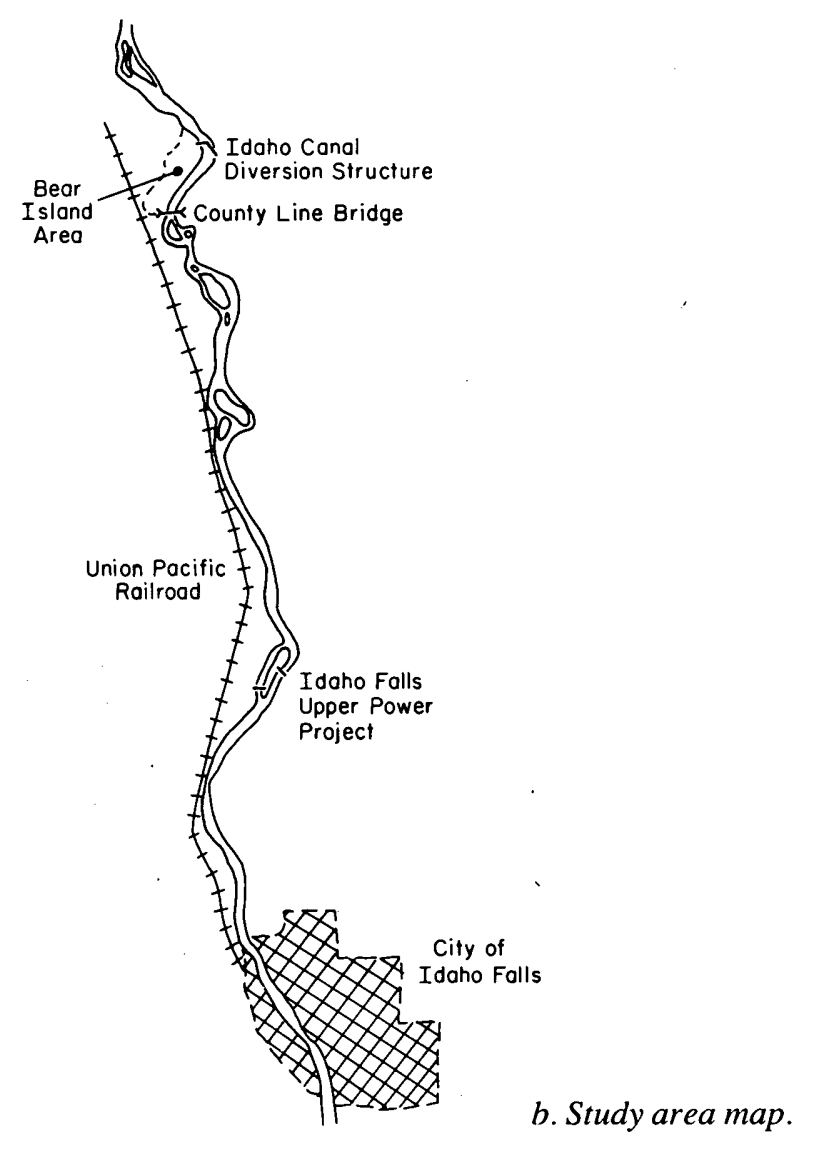

Figure 1. Location and study area maps of Snake River, Idaho.

\section{THE ICE JAM PROBLEM}

The study area is just north of IdahoFalls, in the Upper Snake River drainage basin (Fig. 1). The Snake River and its largest tributary upstream of Idaho Falls, Henry's Fork, both originate in the Yellowstone region. Henry's Fork joins the Snake River about 30 miles upstream of the study site. Flows upstream of the study reach are primarily controlled by the Palisades Reservoir Dam on the Snake River (approximately 80 miles upstream of the study area) and the Island Park Reservoir Dam on Henry's Fork (approximately 90 miles upstream).

The Snake River meanders over a wide floodplain downstream of the Palisades Dam, with the natural river slope steepening near Idaho Falls. The bed slope increases from 0.0002 upstream of the Idaho Canal Diversion Structure to 0.0011 in the study reach. Downstream of the Upper Power Plant, the slope increases to 0.0016. Details of the study reach are shown in Figure 2. Just downstream of the Idaho Canal Diversion Structure, the flow regime is dominated by turbulent riffles. South of the County Line Bridge the river has multiple channels and is characterized by several riffle and pool sections. The river forms a single channel, straightens out, and becomes more tranquil below RM 804 as it enters the backwater of the Upper Power Project reservoir. The deepest part of the river in the study reach is just upstream of Upper Dam 1, where the reservoir is nearly $80 \mathrm{ft}$ deep.

\section{Cause of ice jams \\ in the study area}

Ice jams in the study area are caused by the accumulation of frazil ice beneath and upstream of the sheet ice cover of the Upper Power Project reservoir. As frazil collects at this location, it forms a hanging dam of ice, which causes the river just upstream to rise in stage and slow in velocity. As more frazil arrives, an ice jam forms at the upstream edge of the reservoir behind this ice dam and progresses upstream. The jam shoves and thickens during growth to achieve a balance of forces within the ice, eventually reaching a near-equilibrium ice thickness. The equilibrium thickness of a jam is largely dependent on the hydraulic properties of the river, such as water surface slope, discharge, and river width (Pariset et al. 1966). The flood levels associated with a jam are largely a function of the river discharge and the ice jam thickness. An ice jam will continue to progress upstream as long as a frazil supply is available and the frazil is not carried under the jam and transported downstream by 


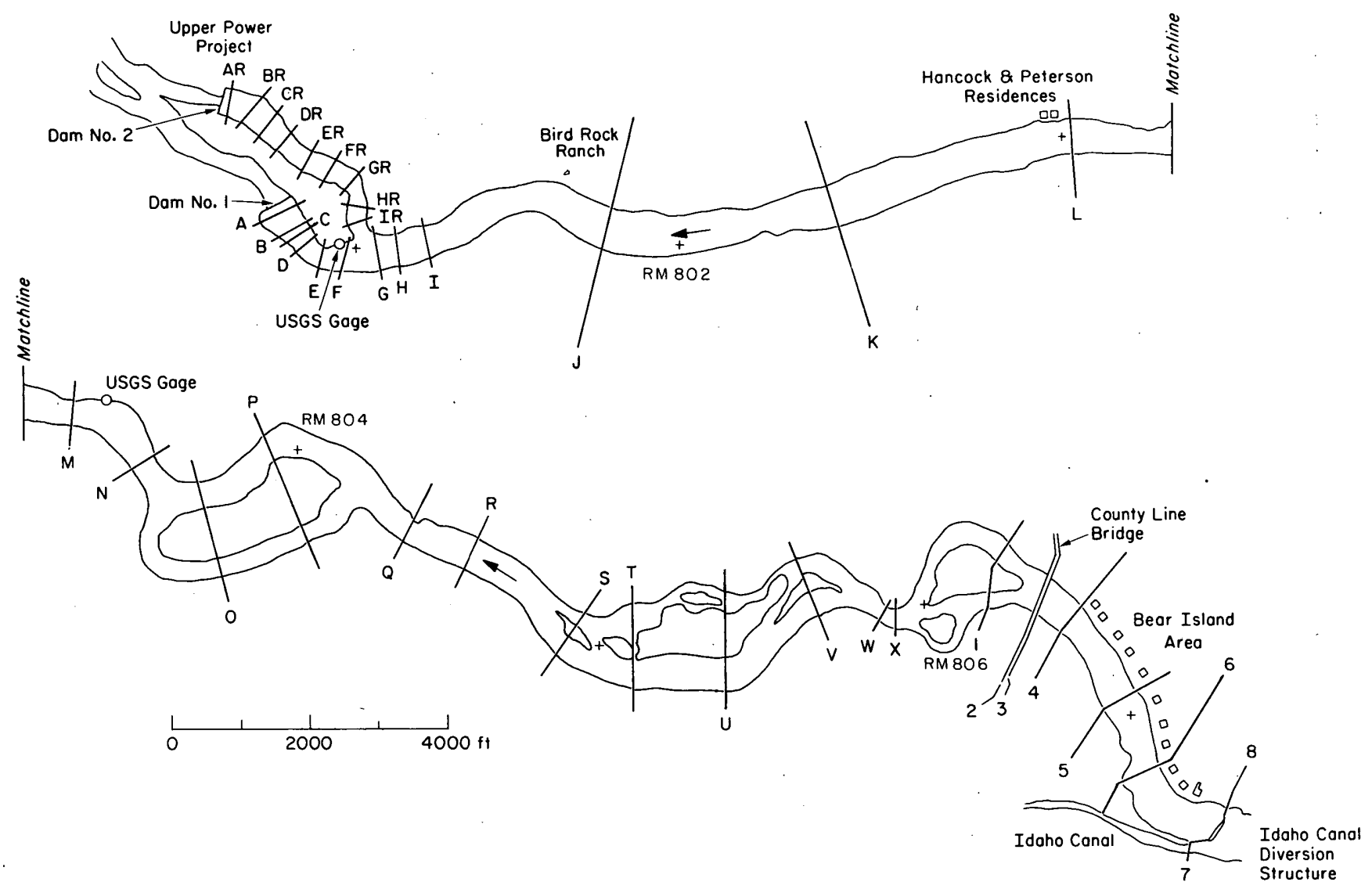

Figure 2. Study reach showing cross-section locations and river miles.

high flow velocities. In the study reach, the jam can progress upstream to the Idaho Canal Diversion Structure under favorable winter conditions.

The majority of the frazil ice causing the jam is produced in the turbulent reaches just downstream of the Idaho Canal Diversion Structure. The extremely mild slope and slow river velocities upstream of the diversion structure allow the formation of a sheet ice cover over many miles of river upstream of the study reach. This sheet ice cover upstream insulates the river and prevents supercooling of the water, inhibiting the production of frazil ice. The upstream cover also traps most of the frazil produced farther upstream. Because of this cover, only a small portion of the frazil contribution to the ice jams in the study reach comes from upstream.

\section{History of}

\section{river ice problems}

Information regarding past ice jam problems in the study area was largely based on interviews with local residents, power project employees and other local and government officials. Since written records of problems were minimal, reconstructing a good history was difficult. Very few people lived along the river before the
Bear Island development was built in the mid-1970s, and only two houses existed along the river in 1948.

The Bear Island residents cannot recall any major ice jam problems from the time of their arrival in the early 1970s until the construction of the new power project in 1982. The earliest reported ice jam flood occurred in January 1958 near the Bird Rock Ranch (RM 801.5), when an estimated 6-8 in. of water stood around the farm buildings, and ice washed into a field upstream. Similar flooding was reported at this location on at least two other occasions between 1950 and 1958. In January 1969 , ice shoved and built up to the top of the riverbank near the Peterson property (RM 803.1), but it caused no flooding. Mr. Peterson raised the level of his backyard $2.5 \mathrm{ft}$ that spring. There were no reported ice jam floods or other problems during the interim period of 19711982.

Peterson's raised backyard was overtopped by an ice jam flood in December 1982, and the gates at the new Dam 1 were lowered at that time in an attempt to reduce the flooding. Peterson reported that the water level began to drop, with a slight movement of ice downstream, within one hour of the gate drop. Residents at low-lying houses in the Bear Island development also 
reported some overbank flooding and apparent flood reductions due to gate lowerings during this period. Peterson raised the level of his backyard another $2.5 \mathrm{ft}$, but an ice jam during the 1983-1984 winter again threatened his property and Bear Island residents. The dam gates were lowered at least five times that winter (21 and 26 December and 18, 19 and 22 January) in attempts to alleviate flood levels, with no apparent success.

The highest ice jam flood levels in the study area reported by residents occurred during the 1984-1985 winter. At about 16:30 on 4 January, the water level reached an elevation of $4742.1 \mathrm{ft}$ IFD (Idaho Falls datum, defined in next section) at the Hancock residence (just north of the Peterson residence). Water stood several inches deep in Mr. Hancock's garage. The USGS gauge just upstream also recorded a peak water surface elevation of $4742.25 \mathrm{ft}$ IFD at this time and went even higher the next day (4743.18 ft IFD). At Bear Island, water came over the bank to the edge of the development's access road just upstream of the County Line Bridge. Farther upstream, at Section 4 (Fig. 2), the water rose to a level of about $4758 \mathrm{ft}$ IFD. Portions of the backyards of the seven houses in the Bear Island development were under water. This flooded area was somewhat smaller in extent than the 100-year flood boundary indicated in a 1979 study by the Corps of Engineers (U.S. Army Corps of Engineers 1979).

\section{History of the \\ Upper Power Project}

The relationship between ice jam problems in the study reach and the changing reservoir levels requires an understanding of the project history and of the vertical survey datums used in the area. The history of the Upper Power Project can be divided into three periods: the time when the original project was under construction and in use (1928-1971), an interim period (1971-1982) when sections of the original control dam were removed from the river and the reservoir level was reduced, and the period since 1982 with the new project under operation.

The determination of reservoir levels during these periods is complicated by the use of at least three different vertical survey datums in the area, by uncertainties as to which datum was used in the past, and by changes in gate operation between the old and new projects. A complete discussion on the evolution of the Upper Power Project and the vertical datums used in the Idaho Falls area is included in Appendix A. In summary, all elevations are referenced to Idaho Falls Datum(IFD), which is the same as the National Geodetic Vertical Datum (NGVD) prior to its 1968 adjustment. For the hydraulic analysis portion of the study, three reservoir elevations were examined: 1) the reservoir elevation of $4736.0 \mathrm{ft}$ IFD for the present dam, 2) the lowest possible level during the interim period with reservoir elevation dependent on discharge over the dam sill at $4726.1 \mathrm{ft}$ IFD, and 3) the pool elevation maintained at $4732.4 \mathrm{ft}$ IFD for the original dams. These three scenarios will be referred to as case 1 , case 2 , and case 3 , respectively.

\section{HYDRAULIC AND METEOROLOGICAL INFORMATION}

Meteorological, discharge and ice data were collected to calibrate the hydraulic analysis of the Snake River and to gain insight into historical ice jam problems in the area. The Walla Walla District, CRREL, and the City of Idaho Falls cooperatively collected a variety of information during the 1985-1986 winter, including field measurements, still photos, and video imagery in order to document changing ice conditions over the winter. Historical weather and discharge data were gathered from federal agencies, the city and local residents.

\section{Air temperature and \\ freezing degree-days}

Daily high and low air temperatures recorded at the Idaho Falls Airport since 1957 were obtained from the National Climatic Data Center (NCDC) and analyzed to determine winter freezing patterns in the area. The cumulative freezing degree-day curve was computed for each winter since $1957-58$ from the average daily temperatures. The peak number of freezing degree-days in a winter season is a rough measure of a winter's severity in temperature and is included in Table 1 for the abovementioned winters. Since frazil production in a river only occurs in subfreezing weather, the peak freezing degree-day number can provide a rough estimate of potential ice problems in a past winter. Ice jam flooding, however, is related not only to cold weather and ice generation but also to river discharge.

\section{Snake River \\ winter discharge data}

The USGS maintains a network of stage-discharge gauges in the Snake River drainage basin. Two USGS gauges currently operate in the study reach. A gauge on the Snake River near Idaho Falls (USGS gauge 13057160), about 2.5 miles upstream of Dam 1 , has been in operation since November 1982. A second USGS gauge has been located $1000 \mathrm{ft}$ upstream of Dam 1 since April 1984. Another gauge, Snake River near Lewisville, was located at the County Line Bridge from June 1978 through November 1982. The Lorenzo (13038500) and Rexburg (13056500) gauges upstream have operated since January 1978 and November 1981, respectively. The USGS gauge on the Snake River at Shelley (13060000) has been in place since March 1915 (al- 
Table 1. Monthly mean discharge, Snake River at Shelley (USGS 1306000).

\begin{tabular}{|c|c|c|c|c|c|c|c|c|}
\hline $\begin{array}{l}\text { Winter } \\
\text { season }\end{array}$ & November & December & January & February & March & $\begin{array}{c}\text { Winter } \\
\text { average* }\end{array}$ & $\begin{array}{c}\text { Ice } \\
\text { Jam? }\end{array}$ & $\begin{array}{c}\text { Peak } \\
\text { degree } \\
\text { days }\end{array}$ \\
\hline \multicolumn{9}{|l|}{ New Dam } \\
\hline 1985-1986 & 3536 & 4098 & 5319 & 5019 & 1319 & 4812 & No & 771 \\
\hline 1984-1985 & 5755 & 7002 & 7350 & 5976 & 5610 & 6776 & Yes & 1140 \\
\hline 1983-1984 & 7841 & 8334 & 8210 & 5393 & 6006 & 7312 & Yes & 922 \\
\hline $1982-1983$ & 5687 & 5693 & 6880 & 5201 & 6180 & 5925 & Yes & 507 \\
\hline \multicolumn{9}{|c|}{ Interim Period } \\
\hline 1981-1982 & 2157 & 2396 & 2264 & 3222 & 9207 & 2627 & No & 605 \\
\hline 1980-1981 & 2735 & 2707 & 2449 & 2571 & 2245 & 2576 & No & 308 \\
\hline 1979-1980 & 2244 & 2732 & 2798 & 3069 & 2558 & 2866 & No & 493 \\
\hline 1978-1979 & 3511 & 5000 & 5598 & 5690 & 7685 & 5429 & No & 1128 \\
\hline 1977-1978 & 2098 & 2381 & 2310 & 2407 & 3655 & 2366 & No & 369 \\
\hline 1976-1977 & 3551 & 5948 & 4800 & 2888 & 1976 & 4545 & No & 824 \\
\hline 1975-1976 & 5015 & 5878 & 6118 & 5889 & 10093 & 5962 & No & 733 \\
\hline 1974-1975 & 5285 & 5146 & 4698 & 4804 & 7403 & 4883 & No & 789 \\
\hline 1973-1974 & 3363 & 3514 & 4030 & 4680 & 7798 & 4075 & No & 574 \\
\hline $1972-1973$ & 5592 & 5743 & 4659 & 5498 & 4548 & 5300 & No & 923 \\
\hline $1971-1972$ & 6511 & 5481 & 5018 & 5748 & 10770 & 5416 & No & 636 \\
\hline
\end{tabular}

Old Dam

\begin{tabular}{lllllllll}
$1970-1971$ & 4358 & 4611 & 4889 & 6377 & 9043 & 5292 & No & 487 \\
$1969-1970$ & 2921 & 2546 & 2851 & 3041 & 2897 & 2813 & No & 285 \\
$1968-1969$ & 3728 & 4978 & 5519 & 5079 & 6284 & 5192 & Yes & 511 \\
$1967-1 g 68$ & 3425 & 4100 & 3908 & 3002 & 3111 & 3670 & No & 762 \\
$1966-1967$ & 2561 & 2842 & 2515 & 2360 & 2300 & 2572 & No & 322 \\
$1965-1966$ & 4727 & 5820 & 4515 & 4657 & 4183 & 4997 & No & 617 \\
$1964-1965$ & 3281 & 4135 & 4633 & 8032 & 10820 & 5600 & No & 480 \\
$1963-1964$ & 2431 & 3593 & 2228 & 2203 & 2766 & 2675 & No & 1375 \\
$1962-1963$ & 2789 & 3588 & 2188 & 3342 & 2452 & 3039 & No & 442 \\
$1961-1962$ & 2299 & 2412 & 1948 & 3579 & 2498 & 2646 & No & 793 \\
$1960-1961$ & 2131 & 2117 & 2212 & 2570 & 2400 & 2300 & No & 454 \\
$1959-1960$ & 3358 & 3175 & 2510 & 2492 & 3031 & 2726 & No & 788 \\
$1958-1959$ & 3058 & 3253 & 3213 & 3290 & 3198 & 3252 & No & 285 \\
$1957-1958$ & 3655 & 3741 & 3318 & 3665 & 3488 & 3575 & Yes & 407 \\
\hline
\end{tabular}

though records for the entire year were not begun until October 1931). Due to its proximity to the study reach (10 miles downstream) and its long data record, this gauge was used for the historical discharge analysis for the Idaho Falls area.

Table 1 summarizes the mean monthly discharges measured at Shelley for the past 29 winters for which air temperature data were available. As stated above, the peak number of freezing degree-days for each winter is also tabulated. No general trends in either the air temperature or the discharges are apparent in these data, but the information from 1977-78 to the present must be noted in relationship to the ice jam problems at Bear Island. Most of the Bear Island development was built in the mid- to late 1970s. Except for 1978-79, the area experienced both mild winters and low discharges from $1977-78$ to $1981-82$. Such conditions would be less conducive to ice jam flooding. The next three winters (1982-83 to 1984-85) were very cold with high discharges, and ice jam flooding occurred in the study area each winter. The high discharges were, in general, a result of very large snowpacks in the Northern Rocky Mountains. Lakes and reservoirs in this area filled to record levels as a result of the snow melt. Flood control reservoirs such as Palisades increased winter releases during this period to accommodate projected spring runoffs. The cold winters and high discharges of 198283 to 1984-85 coincided with the Upper Power Project construction in 1982. Several Bear Island residents reported that smooth ice often covered the river prior to 
1982, while the ice cover was broken and jumbled after that date. This observation would be consistent with higher flows and a greater supply of frazil ice.

A review of the mean daily winter discharges measured at Shelley since 1932 indicates that flow control at the Palisades Dam may have changed the long-term discharge patterns in the study area. In the 23 years of record prior to the construction of the Palisades Dam in 1956-57, there were only three years in which the mean daily flow exceeded $6000 \mathrm{ft}^{3} / \mathrm{sec}$ during December through February. In the 30 years since Palisades began operation, however, this mean daily flow rate has been exceeded in approximately half of the winters. The flow patterns changed because the Palisades reservoir is used primarily for flood control and irrigation (power production is a secondary objective). Spring runoff is stored in the reservoir for use in summer irrigation. In the winter, excess stored water is released both to produce electricity and to accommodate the projected runoff for the next spring. This mode of operation increases the winter flow over that of an uncontrolled river. Due to the series of "wet" winters in the early 1980 s, the highest mean daily discharges for December-February exceeded $7300 \mathrm{ft}^{3} / \mathrm{sec}$ for the first time in 1982. Since that time, flows have exceeded $8000 \mathrm{ft}^{3} / \mathrm{sec}$ every winter and $9000 \mathrm{ft}^{3} / \mathrm{sec}$ in two winters. Such a significant increase in discharge (and river stage) was a significant factor in causing ice jam floods in the study area.

The Palisades Power Dam changed its power generation method from run-of-river to peaking mode, and hence changed its discharge patterns, during the 198586 winter. The peak demand for electricity may be met either by maintaining a higher steady discharge or by semidiurnally cycling flow releases to match the demand peaks. Peaking mode operations at Palisades Dam reduce the mean daily discharge and the length of time at a maximum flow rate. The peak discharge in the study reach would be less than that at Palisades since the flow peaks are attenuated as they move downstream. During the 1985-86 winter Palisades Dam operated on a peaking mode with a target average release of $3500 \mathrm{ft}^{3} / \mathrm{sec}$ during the coldest periods.

It is not clear whether the change in releases at Palisades Dam will help or hurt the ice jam problem in the study reach. The lower average discharges would translate to lower average stages downstream (after the release waves attenuate), which could ease flood problems. The lower average flows may also aid ice cover growth downstream of Palisades, reducing frazil production. However, large fluctuations in river velocity . due to the release cycles may move additional frazil into the study area if the velocities are sufficient to disturb frazil deposits and ice jams upstream. These effects can be determined only through further field measurements.

\section{Field measurements of water level and ice thickness}

City personnel surveyed the water surface elevations along the study reach on 7 March and 9 May 1986, when the mean daily discharges measured at the Idaho Falls gauge (USGS 13057160) were 8700 and $24,600 \mathrm{ft}^{3} / \mathrm{sec}$, respectively. CRREL and Walla Walla District personnel measured ice thicknesses, flow velocities and water levels along the study reach on 8-9 January 1986 , when the ice jam extended from the Upper Power Project Reservoir to RM 805. The mean daily discharge during this time was $3800 \mathrm{ft}^{3} / \mathrm{sec}$. These open-water and icecovered river profile data were vital for this study, as they were used to calibrate the hydraulic model and analysis presented in the next section of this report.

During the 1985-86 winter the ice jam never progressed farther upstream than RM 805, and the river remained open at Bear Island throughout the winter. Table 2 summarizes the ice measurements made on 8-9 January. No frazil ice was present under the reservoir ice cover near the dams. At the upper end of the reservoir, however, frazil had accumulated to form a hanging ice dam $7 \mathrm{ft}$ thick. The frazil accumulations were thinner at

Table 2. Study area ice conditions measured 8-9 January 1986.

\begin{tabular}{lcccccl} 
River & $\begin{array}{c}\text { Number of } \\
\text { measurements } \\
\text { across } \\
\text { mile }\end{array}$ & $\begin{array}{c}\text { Average } \\
\text { ice cover } \\
\text { thickness } \\
(f t)\end{array}$ & $\begin{array}{c}\text { Average } \\
\text { frazil } \\
\text { thickness } \\
(f t)\end{array}$ & $\begin{array}{c}\text { Total } \\
\text { average ice } \\
\text { thickness } \\
(f t)\end{array}$ & $\begin{array}{c}\text { Average } \\
\text { maximum } \\
\text { velocity } \\
(f t / s e c)\end{array}$ & \multicolumn{1}{c}{ Notes } \\
\hline 800.5 & 6 & 1.3 & 0 & 1.3 & 1.5 & Just upstream of Dam 2 \\
800.6 & 8 & 1.3 & 0 & 1.3 & $\approx 0$ & Just upstream of Dam 1 \\
801.5 & 6 & 1.3 & 5.8 & 7.1 & 1.5 & Bird Rock Ranch \\
803.1 & 9 & 1.2 & 5.8 & 7.0 & 1.6 & Hancock/Peterson houses \\
804.0 & 11 & 1.2 & 3.5 & 4.7 & 1.2 & Island in river \\
804.4 & 5 & 1.6 & 1.8 & 3.4 & $*$ & Small island in river \\
\hline
\end{tabular}

* Velocities at RM 804.4 varied from zero (grounded ice) to $>3.3 \mathrm{ft} / \mathrm{sec}$ ) 
the upstream end of the jam, probably because the jam was still evolving at that location.

\section{HYDRAULIC ANALYSIS}

The hydraulic analysis of the Snake River presented in this study, for both open-water and ice-covered river conditions, was based on computations made with the HEC-2 Water Surface Profile computer program with its ice cover option (U.S. Army Corps of Engineers HEC 1982). The hydraulic effects of bridges, culverts, weirs, floodplains and floating stationary ice covers can be investigated using HEC-2. The computational procedure is based on the solution of the one-dimensional energy equation, with friction losses evaluated from Manning's equation. The input data for HEC-2 includes channel cross sections, reach lengths, discharges, ice thicknesses, friction coefficients and a water surface elevation at the downstream hydraulic control.

\section{Calibration of}

the hydraulic model

The HEC- 2 cross sections and reach lengths used to model the study area were obtained from a flood insurance study by the Federal Emergency Management Agency (sections AR-IR and A-L), a city survey for this study (Sections M-X), and the 1979 Corps of Engineers study of the area mentioned above (sections 1-8). The section locations are shown in Figure 2.

The surveyed water elevations of 7 March and 9 May 1986 were used to calibrate the model for open-water conditions at the measured discharges of 8700 and $24,600 \mathrm{ft}^{3} / \mathrm{sec}$. The $8700-\mathrm{ft}^{3} / \mathrm{sec}$ discharge is in the range

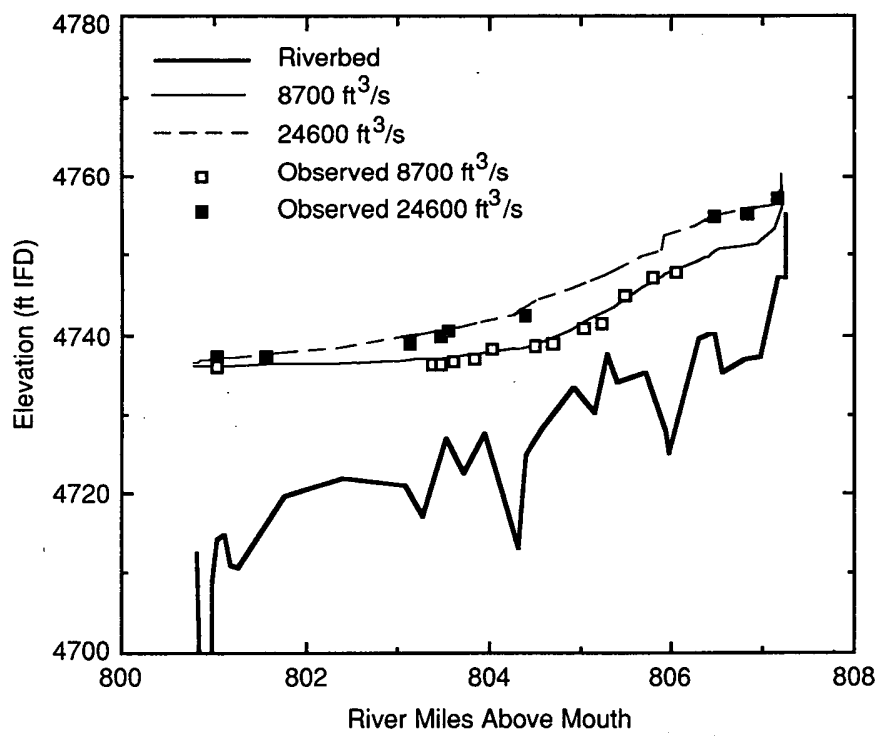

Figure 3. Open-water calibration $-8,700$ and $24,600 \mathrm{ft}^{3} / \mathrm{sec}$. of flow rates measured when ice jams were present, while the $24,600-\mathrm{ft}^{3} / \mathrm{sec}$ flow is typical of spring runoff. Figure 3 plots the computed water surface elevation vs river mile for the two open-water calibration runs, and also shows the measured water surface elevations.

The surveyed water elevations of 8-9 January 1986 and the measured ice thicknesses of those dates (Table 2) were used to calibrate HEC-2 for ice-covered conditions. The width-averaged total measured ice thickness (sheet and frazil) was used at the cross sections. Figure 4 shows the calculated and measured water surface elevations for the ice cover calibration run. For the openwater calibrations, the flow resistance was adjusted within a reasonable range (Manning's $n$ of $0.025-0.045$ ) to match the computed profiles to the field measurements of water surface elevation. For the ice cover calibration, the bed friction (Manning's $n_{b}$ ) found for the open-water calibration was used and only the ice cover roughness coefficient (Manning's $n_{\mathrm{i}}$ ) was adjusted. Ice cover roughness varied from 0.020 for sheet ice to 0.050 for jammed accumulations.

HEC- 2 computes backwater profiles by starting at a known downstream water elevation. The present dam operates with automatic gate adjustment, maintaining a steady pool at an elevation of $4736.0 \mathrm{ft}$ IFD. This starting elevation for the backwater computations was used for the calibration runs and all case 1 discharges, both open water and ice covered.

\section{Open-water computations}

Water surface profiles under ice-free conditions were computed using five discharges for each of the three reservoir elevation cases. The two calibration discharges of 8700 and $24,600 \mathrm{ft}^{3} / \mathrm{sec}$, as well as discharges of 2000 ,

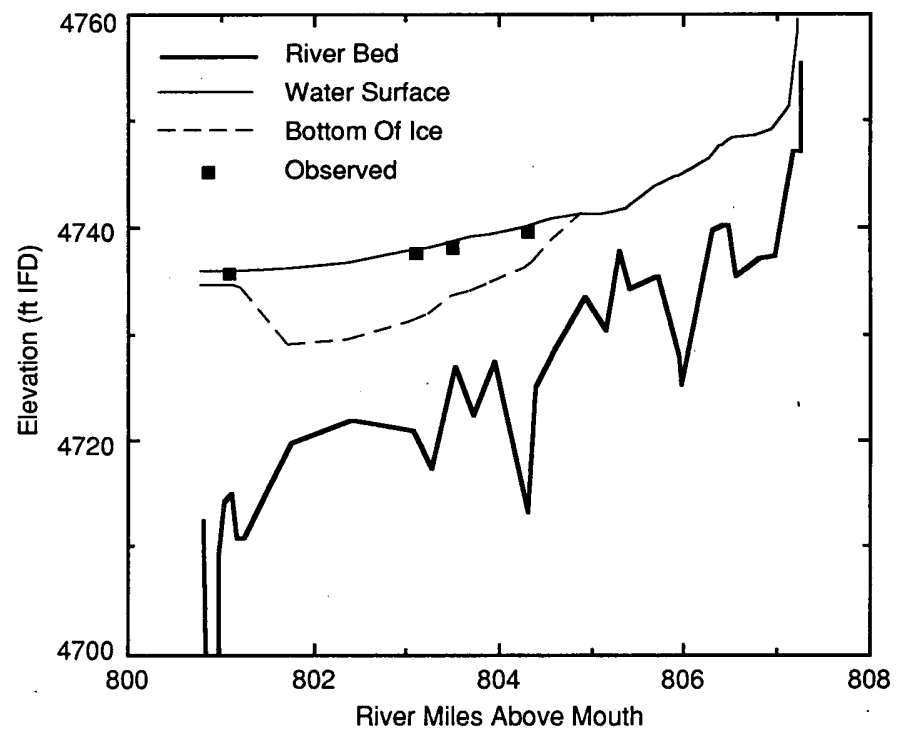

Figure 4. Ice-covered calibration-3,800 ft $3 / \mathrm{sec}$. 
4000 , and $16,000 \mathrm{ft}^{3} / \mathrm{sec}$, were chosen to cover the range of typical open-water discharges experienced throughout the year. The dam or dam gate sill acts as the downstream water level control for all three cases. For case 1 the gates of the present dam are operated to maintain a pool elevation of $4736.0 \mathrm{ft}$ IFD at all discharges. Similarly, for case 3 , the gates of the original dam were operated to maintain a pool elevation of $4732.4 \mathrm{ft}$ IFD at all discharges. As the gates of the original dam deteriorated and became inoperable, however, the pool may have fallen below this target elevation

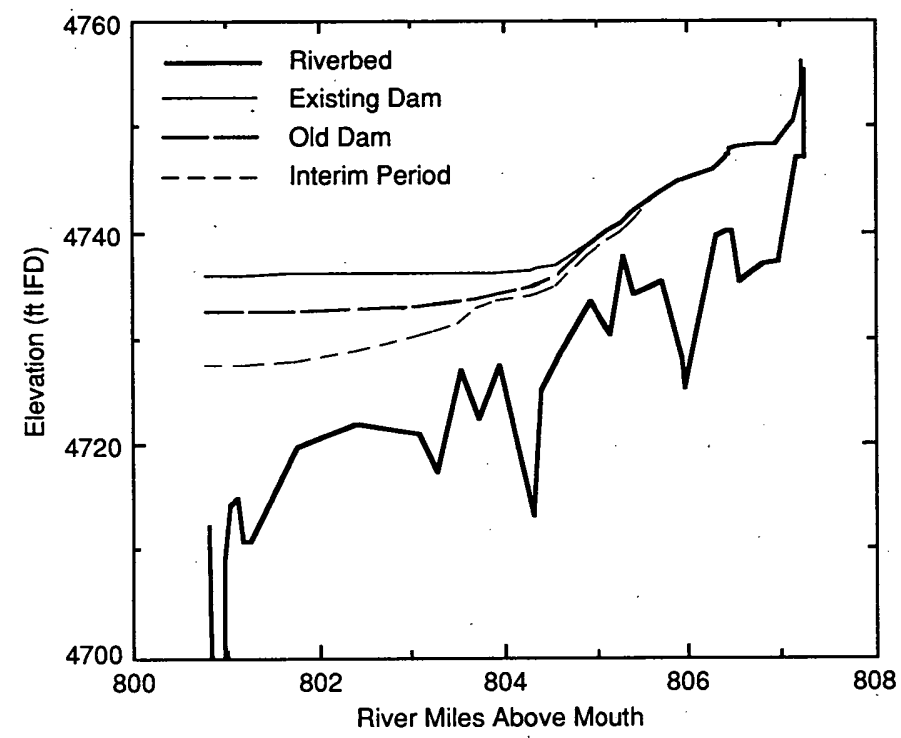

Figure 5. Open-water profiles for the three reservoir elevation cases $-4,000 \mathrm{ft}^{3} / \mathrm{sec}$.

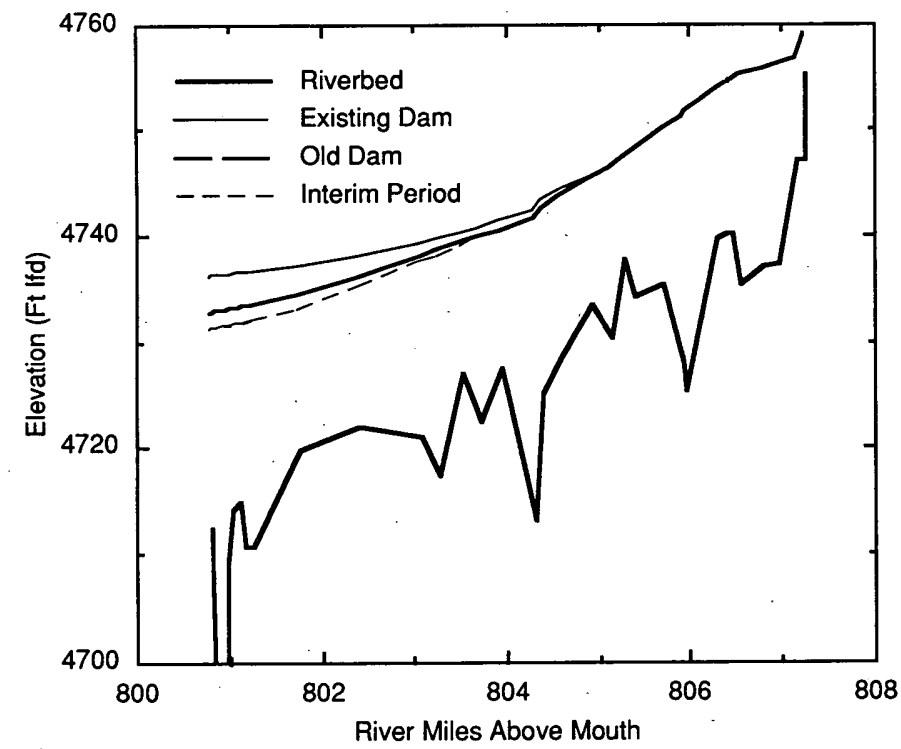

Figure 7. Open-water profiles for the three reservoir elevation cases-24,600 $\mathrm{fi}^{3} / \mathrm{sec}$. during low flow due to leakage. The pool may also have risen above the target elevation during high flows because some gates were inoperable or were replaced by stop logs. For case 2, the level of the reservoir was dependent on the discharge, with the dam sill acting as a broadcrested weir at an elevation of $4726.1 \mathrm{ft}$ IFD.

Figures 5-7 depict open-water surface levels for the three reservoir elevation cases at 4000,8700 and 24,600 $\mathrm{ft}^{3} / \mathrm{sec}$, respectively. These figures show that the present reservoir (case 1) extends approximately to RM 805.0, the original reservoir (case 3) extended to RM 804.0, and

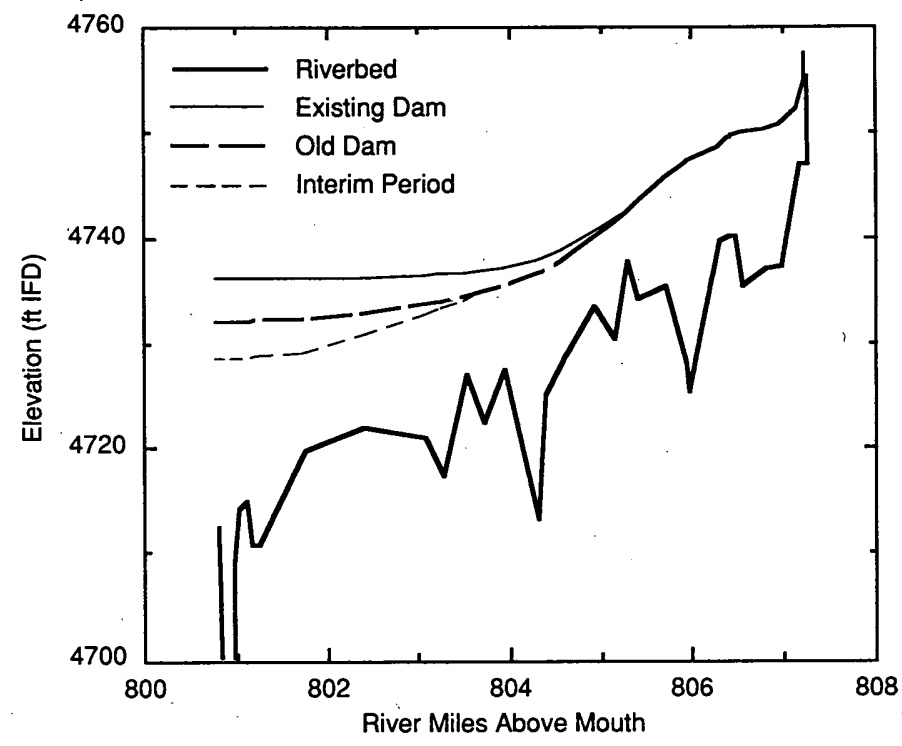

Figure 6. Open-water profiles for the three reservoir elevation cases- $8,700 \mathrm{ft}^{3} / \mathrm{sec}$.

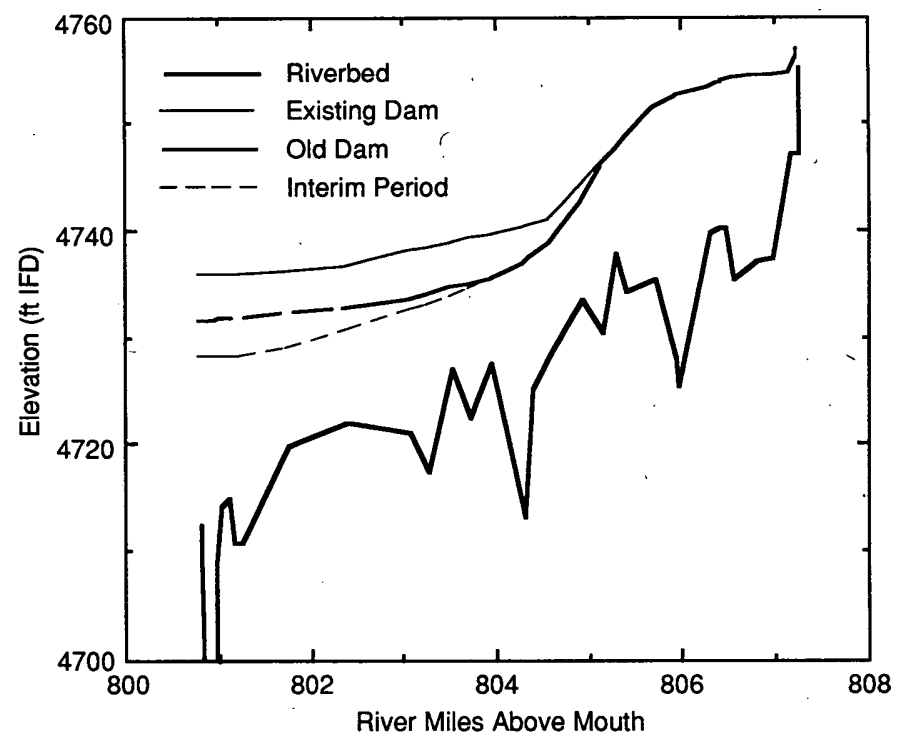

Figure 8. Ice jam profiles for the three reservoir elevation cases-3,800 fi $/ \mathrm{sec}$. 
the residual backwater during the interim period (case 2) only extended to RM 802.0-803.0. Water levels have changed at the Hancock and Peterson residences (RM 803) between the three periods of Upper Power Project operation. At low flows the present dam raised the reservoir level approximately $3 \mathrm{ft}$ over the original level at this site. At high flows, the present level is about $1 \mathrm{ft}$ above the original level. However, Figures 5-7 indicate that, for open-water conditions, Bear Island (RM 806.5807.0) lies well upstream of the hydraulic influence of the Upper Power Project.

\section{Ice cover computations}

HEC-2 simulations of ice-covered conditions for the three reservoir elevation cases were based on equilibrium ice jam theory, field measurements, and historical records. Equilibrium theory considers the force balance on a unit mass of ice in a floating, stationary ice jam. Hydrodynamic and gravitational forces on the ice are balanced by the reaction forces of the riverbanks and the internal strength of the ice. Equilibrium theory (Pariset et al. 1966) provides a reasonable estimate of ice jam thickness when the flow is relatively steady and the water surface is gradually varying. However, in a nonuniform reach where the flow velocity changes rapidly, such as the upstream end of a reservoir, the theory tends to underpredict ice accumulations. At the upstream end of a reservoir, ice transported beneath the cover typically is deposited, resulting in ice thicknesses greater than those calculated by the equilibrium theory. Therefore, the HEC-2 computations were performed with ice thicknesses adjusted accordingly at that location.

Three discharges of 3800,8700 and $10,000 \mathrm{ft}^{3} / \mathrm{sec}$ were used for the ice-covered calculations. The $8700-\mathrm{ft}^{3} / \mathrm{sec}$ value represents recent ice jam discharges, while 10,000 $\mathrm{ft}^{3} / \mathrm{sec}$ was estimated to be the largest discharge for which an ice jam would remain intact. Equilibrium ice thicknesses were calculated at the HEC-2 cross sections for the three ice-covered discharges for each reservoir elevation case. Initial equilibrium thicknesses for each discharge and each reservoir elevation were calculated based on open-water conditions. A trial and error process of substituting calculated thicknesses into HEC-2, recomputing the water surface elevations, and then recalculating equilibrium ice thickness eventually led to stable ice thicknesses for each discharge. When the calculated equilibrium thicknesses for $3800 \mathrm{ft}^{3} / \mathrm{sec}$ under case 1 were compared to the average measured ice thicknesses of 8-9 January 1986, the values matched well, except for the upstream end of the reservoir (RM 801.7-803.6). As mentioned above, a hanging ice dam typically forms under the ice cover at this location. Based on a comparison of measured and calculated ice thicknesses for the $3800-\mathrm{ft}^{3} / \mathrm{sec}$ discharge (under case 1), the ice thicknesses at the upstream end of the reser- voir were adjusted for other discharges (for each reservoir elevation case).

Backwater profiles for 3800 - and $8700-\mathrm{ft}^{3} / \mathrm{sec}$ discharges were computed for the present dam (case 1) with these calculated ice jam thicknesses, and the resulting water levels were compared to the ice jam flood of 4 January 1985 . The water level for that jam rose to a peak level of $4742.1 \mathrm{ft}$ IFD at the Hancock and Peterson houses (RM 803) when the daily average discharge was $8050 \mathrm{ft}^{3} / \mathrm{sec}$. This water level was very close to the 8700 $\mathrm{ft}^{3} / \mathrm{sec}$ computed level in Figure 9. The 1985 ice jam indicated that ice accumulation in the upstream end of the reservoir can raise water levels significantly in this reach (RM 803-805), effectively reducing the length of the backwater of the dam.

Discharge and ice conditions very probably can combine to cause an ice jam flood more severe than the January 1985 event. With no other flood marks in the study area and with limited records for the Idaho Falls USGS gauge in the present reservoir, statistical estimates of flood levels caused by the ice jams cannot be developed. An examination of the discharge records available for the study area and the velocities obtained for the $8,700-\mathrm{ft}^{3} / \mathrm{sec}$ ice jam provided the estimate that $10,000 \mathrm{ft}^{3} / \mathrm{sec}$ should be considered the highest flow for which an ice jam could remain in place. Water surface elevations were calculated for this discharge with equilibrium ice thicknesses for the three reservoir elevation cases. With the present dams, the $10,000-\mathrm{ft}^{3} / \mathrm{sec}$ ice jam flood levels at the Hancock home would be $1.4 \mathrm{ft}$ higher than during the 1985 flood peak $\left(8050 \mathrm{ft}^{3} / \mathrm{sec}\right)$. At Bear Island the water level would rise another $1.3 \mathrm{ft}$ beyond the computed flood level for an $8700-\mathrm{ft}^{3} / \mathrm{sec}$ ice jam event.

Figures 8-10 depict the ice jam stages for the three historical reservoir levels at discharges of 3800,8700 and $10,000 \mathrm{ft}^{3} / \mathrm{sec}$, respectively. It can be seen that the Hancock and Peterson homes have always been affected by ice jams (except during the interim period when no reservoir existed at that location). It can also be seen that the present reservoir level (case 1) raises the ice jam flood levels at this location over the original reservoir levels (case 3) by, at most, $3.6 \mathrm{ft}$ for all discharges. The figures also indicate that Bear Island remains outside the reservoir influence for all three cases and that high water levels in this area are due solely to the discharge, hydraulic characteristics, and equilibrium ice thickness.

In the upstream part of the study reach (RM 805.0807.5), equilibrium ice thicknesses were used to compute all of the ice-covered water surface profiles in Figures $8-10$. These thicknesses were not verified by field measurements but three points support the use of equilibrium theory in this reach:

1. Large increases beyond the equilibrium thicknesses in the Bear Island reach would raise the river stage up to the low chord of the County Line 


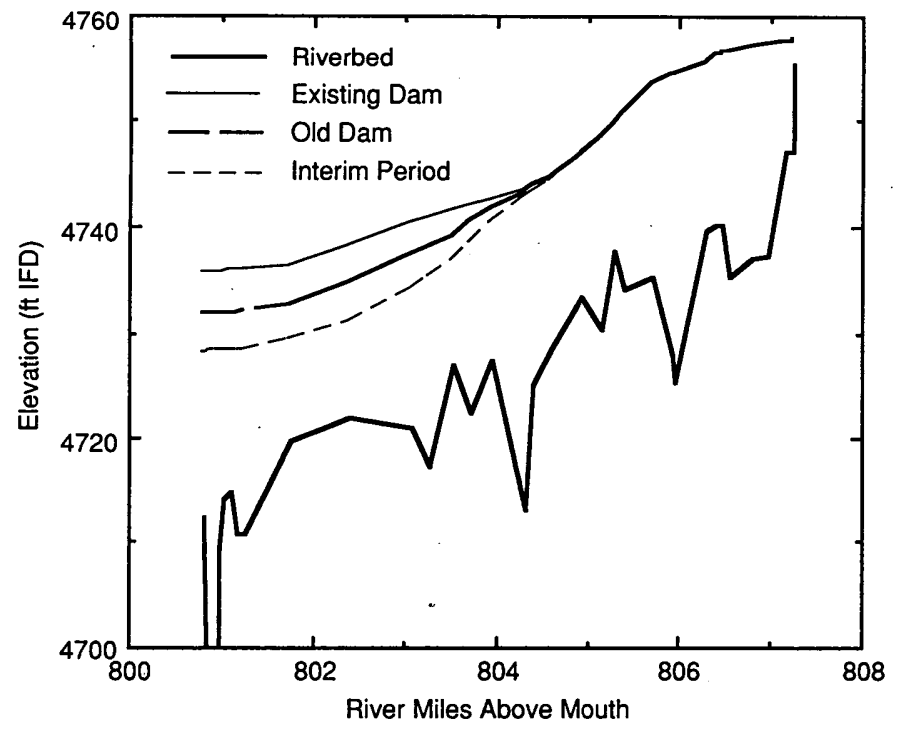

Figure 9. Ice jam profiles for the three reservoir elevation cases $-8,700 \mathrm{ft}^{3} / \mathrm{sec}$.

Bridge. There are no reports of water or ice reaching the low chord of the bridge during the highest recorded ice jam flood.

2. Rough estimates of flood elevations at Bear island during the January 85 event (backyard elevations) agree well with the calculated profile using the equilibrium ice thickness.

3. The reservoir does not influence the flow regime in this reach and thus the assumption of uniform flow inherent in equilibrium thickness theory is a satisfactory estimate.

\section{Summary of computations}

A comparison of the computed open-water surface profiles using different reservoir elevations at the Upper Power Project indicates that the backwater from the present dam extends approximately to RM 805.0 (depending on the discharge), while the backwater of the original dam extended to about RM 804.0. The Hancock and Peterson properties at RM 803 have, therefore, been influenced by both the original and the present power dams. In the interim period (1971-1982) the water levels at these properties were probably not influenced by water flowing over the gate sill of the original dam. The open-water profiles clearly show that Bear Island is well upstream of the reservoir backwater; thus, open-water levels at Bear Island have not been influenced by any of the three reservoir level cases.

Analysis of the ice-covered backwater profiles (Fig. $8-10$ ) indicates that the river stage at the upper end of the reservoir is governed by the discharge, reservoir elevation, and the accumulation of frazil in the upper end of

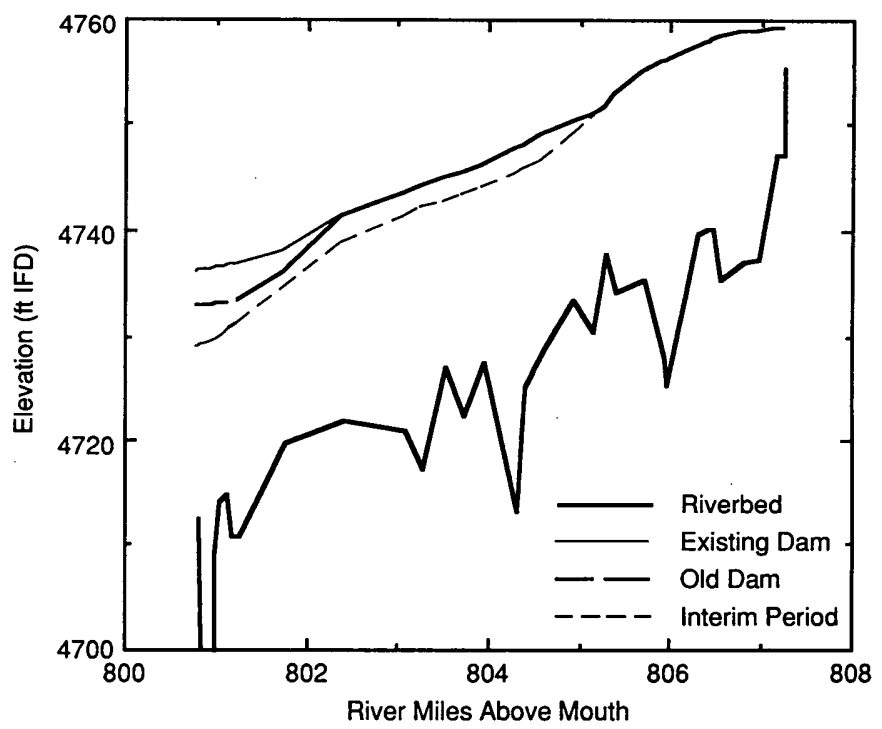

Figure 10. Ice jam profiles for the three reservoir elevation cases-10,000 $\mathrm{ft}^{3} / \mathrm{sec}$.

the reservoir. The amount and distribution of frazil deposition in the upper end of the reservoir is a function of the undercover frazil transport and the flow velocities at that location. Because equilibrium theory underpredicts the ice thickness in this reach, this study has utilized available field data and historical records to develop realistic estimates of ice thicknesses and of river levels due to ice jamming.

Based on the results of ice-covered backwater computations, Figures 8-10 indicate that ice jam flood levels at Bear Island have not been influenced by hydraulic conditions downstream at the Upper Power Project under any of the three reservoir level cases. The Hancock and Peterson properties at RM 803 are affected by frazil deposition in the upper end of the reservoir. The worst case estimates of ice jam stages (Fig. 10) indicate that reservoir level changes between the original and present dams have had no noticeable effect on ice jam levels at the two houses because of the small extent of the backwater at this high discharge. During the interim period, the potential ice jam flood levels were lower than those of the present reservoir up to about RM 805.5. Above this location, the ice jam flood levels are the same for all three reservoir elevation cases.

\section{POSSIBILITIES FOR ICE JAM FLOOD MITIGATION}

Several alternatives exist for mitigating ice jam flood damage in the study area. This section of the report lists their effectiveness in reducing ice jam (and open water) 
Figure 11.Ice jam profile for present project at 10,000 $\mathrm{ft}^{3} / \mathrm{sec}$ showing approximate bank elevations.

flood levels but not their economics or cost/benefit ratios.

\section{Levees}

Levees offer substantial protection to flood-prone areas against both ice jam floods and severe runoff events. Figure 11 plots the extreme ice jam flood level with the present dam (from Fig. 10) against the bank elevation profile for the study area. This figure indicates that levees could be effective in four sections of the study area: near Bird Rock Ranch (RM 801.2-801.6), upstream of the Hancock and Peterson houses (RM 802.9803.7), at RM 804.2-804.6, and at lower Bear Island (RM 806.2-806.6). Levees should be well protected by riprap to prevent damage during ice jams. Setback levees are more effective for ice jam conditions than levees at the river's edge because they provide overbank flow area when the river channel is clogged with ice.

The 1979 study performed by the U.S. Army Corps of Engineers found that the lower $1700 \mathrm{ft}$ of the Bear Island development, upstream of the County Line Bridge, is within the 100 -year floodplain. The study concluded that a levee to protect against spring runoff floods would be useful but could not be economically justified. No consideration was given to ice jam flooding at that time.

\section{Ice control structures}

The turbulent riffle section of the river just downstream of the Idaho Canal Diversion Structure is the primary frazil ice source for ice jams in the study reach. An ice control structure could be placed in this section of the river to reduce velocities, trap frazil and promote early growth of an ice cover. Early formation of an ice cover in this area would reduce the frazil produced for the jam downstream. An ice control structure at this

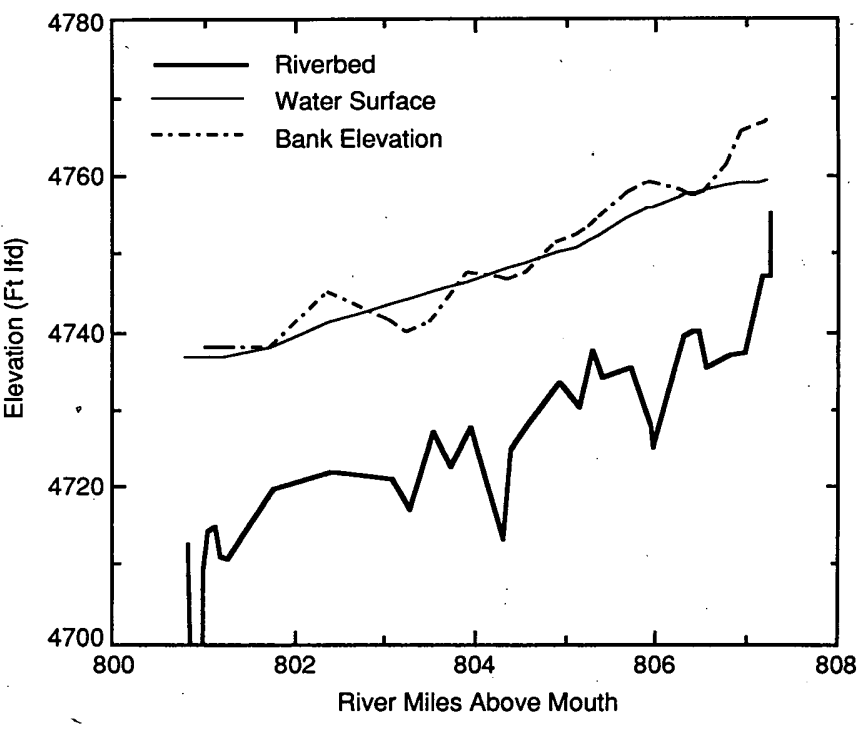

location would require a weir to raise water levels and reduce the locally steep river slope and rapid flow velocities. An ice boom just upstream of the Idaho Canal Diversion Structure might aid in promoting the growth of the ice cover farther upstream earlier during the freeze-up period and thus reduce the amount of frazil entering the Bear Island reach.

\section{Purchase of affected property}

Since relatively few residences in the study area can be considered affected by ice jam floods, the purchase of these properties may be an expedient method of mitigating flood damages.

\section{Palisades Dam flow control to promote ice cover growth}

The total frazil production in a river reach during a winter can be substantially reduced by promoting the early formation of an ice cover on the river surface. The ice cover insulates the river from subfreezing air temperatures. An ice cover cannot easily form on highvelocity reaches of a river. Since the flow velocity is related to the river discharge, one method of lowering velocities and promoting ice cover growth is to reduce the river discharge at upstream control points. This technique has been used successfully on the St. Lawrence River, the Allegheny River and on European rivers to reduce ice jam threats.

Palisades Dam controls the flow through the study area. The discharge at Palisades Dam would have to be reduced to a level such that an ice cover would form easily in the study area during the first cold period of the winter. After a suitable ice cover formation period, discharges at Palisades could be gradually restored to normal operating levels (provided that the change in 
discharge was not too sudden) without disturbing the ice cover downstream. A detailed analysis of stage and discharge levels (which is beyond the scope of this report) would have to be conducted in order to determine the proper target discharge levels. This flow control, in conjunction with use of ice control structures near the Idaho Canal Diversion Structure, could significantly reduce frazil production in the study area.

The Bureau of Reclamation operates the Palisades Dam and other major flow control points upstream of the study area, and this type of ice control program would have to be coordinated with that agency.

\section{Palisades Dam flow control during flood emergencies}

Water levels during flood threats in the study area can be lowered by reducing the discharge at Palisades Dam. However, the travel time for a reduction wave between Palisades Dam and the study reach is at least 24 hours. For this type of emergency operation to be effective, accurate river monitoring and weather forecasts would be necessary. Discharges would have to be reduced to some target value whenever ice jam flooding threatens the Bear Island reach, perhaps when water levels are rising and subzero air temperatures are predicted. Again a detailed analysis of stages, discharges and wave travel times under ice conditions would be required to determine target discharge levels and lag times. Such emergency operations may result in unnecessary flow reductions at certain times.

\section{Gate operations at the Upper Power Plant}

As noted earlier, the gates at the Upper Power Project have been lowered several times in the past in an attempt to alleviate flood threats at the Hancock and Peterson properties. The records of Mr. Hancock and the results of this study indicate that such gate drops do lower flood levels slightly in the reservoir and are thus marginally useful for flood threats at the Hancock and Peterson properties (RM 803).

The residents at Bear Island have also reported that flood levels dropped in their area some time after the gates were lowered at the Upper Power Project. Since the field data needed to establish a direct cause-and-effect relationship between gate reductions and flood level "reductions at Bear Island were not available, this claim could not be proven. The results of the HEC- 2 analysis clearly show that changing reservoir levels have no effect on ice jam flood levels at Bear Island. Since HEC2 is a steady-state hydraulic model and does not account for the effects of surge waves and other transients, the analysis does not rule out the possibility that gate drops might cause temporary flood level reductions at Bear Island. It is also possible that the gate drops might cause a localized increase in discharge throughout the study reach. An increase in discharge would result in shoving and thickening of the cover and quite transient water levels. Without good field data, the cause-and-effect relationship between gate drops and water level reductions at Bear Island could neither be proven nor disproven by the results of HEC- 2 .

Several techniques to reduce the gate level at the Upper Power Project could be used, and their effectiveness on flood mitigation can be generally assessed from the results of this study. One method would be to drop the dam gates either completely or partially in the early winter and keep the reservoir level low throughout the ice jam season. The hydraulic analysis clearly shows that this method will have no effect on ice jam levels upstream at Bear Island.

The dam gates could also be lowered suddenly, either partially or completely, during imminent flood threats at Bear Island. This method may or may not give temporary flood relief to Bear Island. During a rapid gate drop, a negative wave would be sent upstream, locally increasing discharge, which could result in the jam thickening and higher water levels. Also, a rapid gate drop would send a positive wave downstream, possibly breaking existing ice covers downstream, increasing the potential for flooding. This type of transient analysis is beyond the scope of HEC-2. A detailed field measurement program during a gate drop would give the best answers as to its effectiveness.

\section{Doing nothing}

Although the threat of flooding has been fairly frequent in recent years, the actual damage has been limited. Worse flooding is certainly possible, and flow conditions favorable to ice jam flooding have probably been more conducive than normal during 1982-1986. If development continues in the flood-prone areas without consideration for the potential flood threat, the damage from future flooding will continue to increase.

\section{GATE DROP TESTS}

This section of the report details a gate drop test recommended by CRREL to determine the effect on flood levels at Bear Island. As mentioned above, in prior winters when there was a flood threat at Bear Island, the City of Idaho Falls was directed by the county civil defense chief to drop the gates of Dam 1. Records of the effects of these gate drops on water levels upstream do not exist, although residents at Bear Island contend that there were resultant drops in water levels at their location. CRREL recommended that a detailed set of water elevations along the study reach be taken if this practice was repeated. On 22 January 1987, the city dropped the 
gates at Dam 1 of the Upper Power Project and recorded the change in water levels over time throughout the study reach. Water levels were measured every half hour at five stations along the river for a period of five hours. The gate was then slowly raised and power generation resumed four hours later, after the reservoir filled.

The conditions leading up to the test were as follows. A cold snap beginning on 14 January resulted in the entire river from the Upper Power Project dams to Bear Island being covered over with ice by 15 January. The water level at Bear Island fluctuated because of shoving and thickening of the ice cover on 15 and 16 January, rising $3 \mathrm{ft}$ and then falling $1.5 \mathrm{ft}$. From 17 January until the tests, the water level throughout the study reach was stable aside from a diurnal fluctuation of about $0.4 \mathrm{ft}$. This variation was due to the operation of Palisades Dam (for power production) upstream.

These river conditions resulted in 22 January being a most opportune time for the gate drop tests. The stable water level and ice conditions prior to the test would ensure that any water level changes would result from the gate drop and not from the shoving and thickening action of an evolving ice cover. Also, any ice movement in the test reach would be the result of the localized increased discharge in the reservoir area caused by the draining to a lower pool level. There would, however, be a small drop in the water levels expected from the diurnal fluctuation of releases from Palisades Dam, which would amount to no more than $0.1 \mathrm{ft}$ over the duration of the test. The average discharge during the test was 4400 $\mathrm{ft}^{3} / \mathrm{sec}$.

The test began at 1000 hours (MST) on 22 January 1987. Over five hours of observation, the following water level changes were measured. Immediately upstream of the dam, there was a drop in water level of 4.6 $\mathrm{ft}$. A drop of $0.4 \mathrm{ft}$ was recorded at the Hancock residence, which is located in the upper third of the reservoir. At the upstream end of the reservoir (RM 805), there was a water level drop of $0.2 \mathrm{ft}$. The two observation points corresponding to the upper and lower ends of Bear Island both registered a water level drop of $0.1 \mathrm{ft}$. Table 3 gives the readings of water level vs time for the five measuring stations. As was stated above, a water level drop of 0.1 $\mathrm{ft}$ was expected throughout the test reach due to the discharge fluctuation at Palisades Dam. These data show that the areas upstream of the reservoir pool are not affected by gate drop operations. The test also showed that the water levels in the Hancock and Peterson residence area are minimally affected by the gate drops.

Initially, it was thought that a sudden drop in the pool level might cause the ice cover to shift and consolidate in the lower reaches of the reservoir as well as result in

Table 3. Gate drop test-22 January 1987.

\begin{tabular}{|c|c|c|c|c|c|c|}
\hline Time & $\begin{array}{c}A \\
\text { Elevation }\end{array}$ & $\begin{array}{c}B \\
\text { Elevation }\end{array}$ & $\begin{array}{c}C \\
\text { Elevation }\end{array}$ & $\begin{array}{c}D \\
\text { Elevation }\end{array}$ & $\underset{\text { Elevation }}{E}$ & $\begin{array}{c}\text { Temperature } \\
\text { at Idaho Falls } \\
\left({ }^{\circ} \mathrm{F}\right)\end{array}$ \\
\hline 1000 & 35.7 & 39.3 & 48.4 & 54.57 & 58.03 & 5 \\
\hline 1030 & 35.7 & 39.3 & 48.4 & 54.61 & 58.03 & - \\
\hline 1100 & 34.0 & 39.3 & 48.4 & 54.56 & 58.03 & 9 \\
\hline 1130 & 31.5 & 39.2 & 48.4 & 54.55 & 58.03 & - \\
\hline 1200 & 31.1 & 39.2 & 48.4 & 54.56 & 58.03 & 13 \\
\hline 1230 & 31.1 & No reading & No reading & 54.46 & No reading & - \\
\hline $1300^{\prime}$ & 31.1 & 39.1 & No reading & 54.49 & 57.94 & 16 \\
\hline 1330 & 31.1 & 39.0 & 48.3 & 54.49 & 57.95 & - \\
\hline 1400 & 31.1 & 38.9 & 48.3 & 54.45 & 57.95 & 17 \\
\hline 1430 & 31.1 & 38.9 & 48.2 & 54.45 & 57.95 & - \\
\hline 1500 & 31.1 & 38.9 & 48.2 & 54.44 & 57.95 & 19 \\
\hline Total & & & & & & \\
\hline
\end{tabular}

All elevations are $4700 \mathrm{ft}$ plus, Idaho Falls datum

* Gage bottomed at 4731.1, total reservoir drop greater

Locations

A-Immediately upstream of Dam No. 1 (RM 800.80)

B-Hancock residence (RM 803.15)

C-Cross section U (RM 805.37)

D-Bear Island-downstream end (RM 806.47)

E-Idaho Canal Diversion Structure (RM 807.23) 


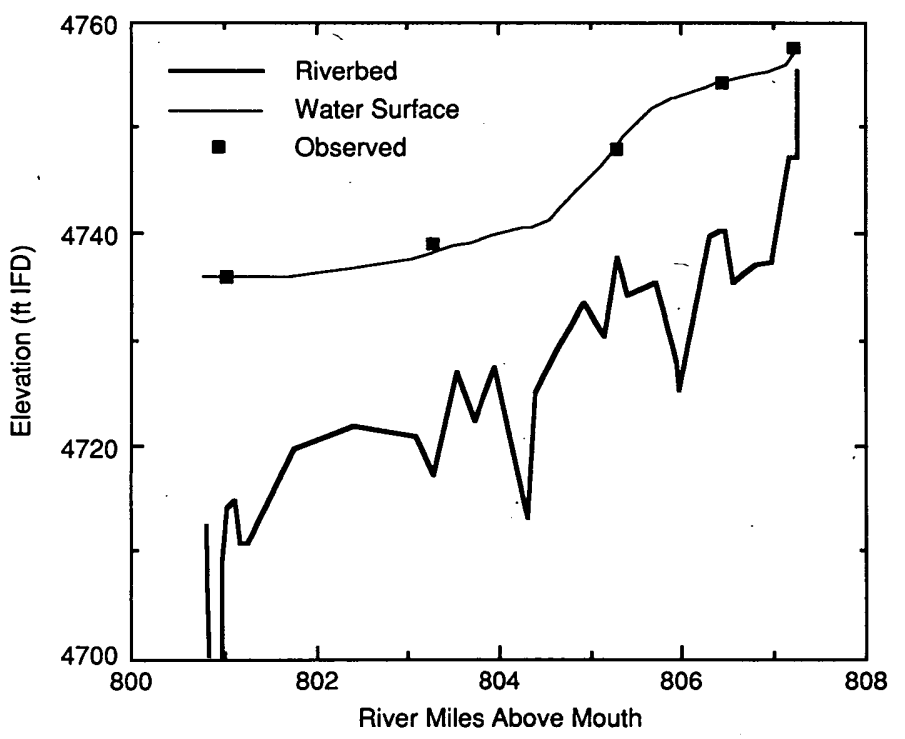

Figure 12. Ice jam profile for present project at $3,800 \mathrm{ft}^{3} / \mathrm{sec}$, showing observed water surface prior to gate drop tests $\left(4,400 \mathrm{ft}^{3} / \mathrm{sec}\right)$. ice being passed over the dam gates. Although a 5 -ft drop of the gates over 20 minutes can be considered a sudden drop, the test demonstrated that it is not rapid enough to cause the ice cover to consolidate or pass over the dam gates. The ice cover on the reservoir simply dropped with the water elevation and was visibly resting on the bed along the shorelines. The ice cover remained stable during both the water level decrease and subsequent increase when the reservoir was refilled to its original pool level following the test.

Some residents of Bear Island contended that the test was not run for a long enough period of time. The only data that could have been obtaiped by running the test for longer than five hours would be the diurnal fluctuation of stages throughout the entire test reach. The measurements of stage during the test showed that the reservoir had drained to its new, lower level (outflow equaled inflow) after about 1.5 hours. The stage at the upper end of the reservoir had also stabilized by the end of the fivehour test. Since the stage at Bear Island is not affected by the reservoir level, any changes in stage at that location would be due only to the diurnal fluctuation (power releases from Palisades Dam).

These tests clearly confirmed the conclusions reached by the HEC- 2 analysis. The stages at the Bear Island area are not affected by the reservoir level under open-water or ice-covered conditions. The reliability of the HEC-2 model is demonstrated by plotting the stages measured throughout the test reach just prior to the gate drop on Figure 12 (water surface levels for $3800-\mathrm{ft}^{3} / \mathrm{sec}$ icecovered flow). These data points are within $0.5 \mathrm{ft}$ of the $3800-\mathrm{ft}^{3} / \mathrm{sec}$ profile (the discharge at the time of the test was estimated to be $4400 \mathrm{ft}^{3} / \mathrm{sec}$ ).

\section{RECOMMENDATIONS AND CONCLUSIONS}

Ice jams in the study area are caused by frazil produced in turbulent open-water sections of the Snake River. The primary frazil source for the ice jam upstream of the Upper Power Project is the riffle reach just downstream of the Idaho Canal Diversion Structure (RM 806.5807.2). The results of this study show that the changing reservoir levels upstream of the project since 1928 have had no direct effect on ice jam flood levels upstream of RM 805. Therefore, the dams have neither caused nor aggravated ice jam problems at Bear Island. Changing reservoir levels have had a noticeable effect on flood levels within the reservoir, notably at the Hancock and Peterson properties (RM 803).

There are several flood mitigation alternatives. Without regard to cost, the alternatives that would provide the most benefit are levees, ice control structures, or property purchase. Flow control at Palisades is a promising but untested alternative. Gate reductions at the Upper Power Project offer minimal flood relief to the Hancock and Peterson residences and provide no mitigation to the ice jam flooding at Bear Island.

The U.S. Army Corps of Engineers, Walla Walla District, and CRREL recommended the following steps to mitigate and control ice jam flooding between the Upper Power Project and the Idaho Canal Diversion Structure:

1. Economic and cost-benefit evaluations should be made for the flood mitigation alternatives presented. 
2. A water level monitoring system for the affected areas should be developed and implemented, if the chosen mitigation method requires this information.

3. Jefferson and Bonneville counties should be encouraged to establish flood zoning on lands adjacent to the Snake River to assure that future development will not be subject to flood damage.

4. The City of Idaho Falls and U.S. Bureau of Reclamation should work together to develop an experimental program for flow control at Palisades Dam to evaluate the effectiveness of this method on ice jam reduction.

The City of Idaho Falls decided to purchase the properties affected by the Upper Power Project, the Hancock and Peterson residences. The City also concluded that the Upper Power Project does not aggravate naturally occurring ice jamming located upstream of the reservoir.

\section{LITERATURE CITED}

Ellsworth, D. M. (1968) An investigation for the rehabilitation of Dam No. 1 and Dam No. 2, Upper Power Plant. Report prepared for the City of Idaho Falls by Donald M. Ellsworth and Associates, Consulting Engineers, Idaho Falls, Idaho.

Pariset, E., R. Hausser and A. Gagnon (1966) Formation of ice covers and ice jams in rivers. American Society of Civil Engineers, Journal of Hydraulics, 97(H46): 1-24.

U.S. Army Corps of Engineers (1979) Upper Snake River flood damage reduction study. U.S. Army Corps of Engineers, Walla Walla District, Walla Walla, Washington.

U.S. Army Corps of Engineers Hydrologic Engineering Center (1982) HEC-2 water surface profiles user's manual. The Hydrologic Engineering Center, Davis, California. 


\section{APPENDIX A: HISTORY OF THE UPPER POWER PROJECT AND VERTICAL SURVEY DATUMS}

Two vertical survey datums are currently in common use around the Idaho Falls area. The USGS maintains a national network of survey benchmarks tied to a common datum known as the National Geodetic Vertical Datum (NGVD), first established in 1929. Since NGVD is generally related to "mean sea level," the USGS occasionally adjusts the NGVD datum. The last major adjustment occurred in 1968, when all NGVDelevations had $0.66 \mathrm{ft}$ subtracted from them. Hydraulic and topographic information obtained from U.S. Government agencies for this study was referenced to the current NGVD. The City of Idaho Falls continues to use the uncorrected, pre-1968 NGVD as the city datum. This datum is referred to in this report as the Idaho Falls Datum (IFD).

Prior to the investigations associated with this study, the spillway crest elevation of the Upper Power Project control dams was believed to be at $4734.7 \mathrm{ft}$ IFD. Inconsistencies between field data and computed water levels (and a resurvey by the City) led to the discovery that the crest elevation is actually at $4736.0 \mathrm{ft}$ IFD, a 1.3$\mathrm{ft}$ difference. An investigation by the city surveyor indicated that the present project elevations were referenced to a local benchmark on the original power house. There is a reasonable indication that the original project elevations were also referenced to the same datum (to be called the Power Dam Datum, or PDD). Since the original structures were torn down to build the present power project, however, this assumption could not be verified.

Neither design nor as-built drawings of the original power project were available for this study. However, the structures were surveyed in 1968 , to evaluate the costs of rehabilitation, and drawings were produced (Ellsworth 1968). Some confusion exists as to the actual datum used for these drawings, as they refer to "U.S.C. and G.S. 1929 Sea Level Datum." This datum was assumed to be NGVD before the 1968 adjustment (in other words, IFD). However, when the city checked with the surveyors about the benchmark they used as an elevation datum, they replied that the benchmark on the powerhouse was used. If this is the case, the elevations listed in the 1968 drawings would be at PDD. The datum question for the original project was not resolved during this study, so the effects of each datum were considered in an evaluation of reservoir levels behind the original dams.
The original control dam in the east channel of the river (Dam l) consisted of a concrete sill and spillway with 20 tainter gates, each $6.25 \mathrm{ft}$ high by $18 \mathrm{ft}$ wide. The power dam in the west channel (Dam 2) consisted of a powerhouse flanked by gated spillways on either side. The power dam had two 8 -ft-high $\times 18$-ft-wide gates on the west side of the turbines, and four similar gates on the east side. The east gates had a sill elevation $0.4 \mathrm{ft}$ lower than the west gates. A maximum of about $2000 \mathrm{ft}^{3} / \mathrm{sec}$ passed through the turbines.

The original power project maintained control of the river until April 1971. By that time the gates and operating machinery had deteriorated to the point where several of the gates in Dam 1 no longer worked. Three of these nonoperable gates had been removed prior to 1971 and replaced by stop-logs. River control using stop-logs was not precise; they were taken out during spring flows and replaced during low flows. During the winter, the working gates would often ice up and cease functioning, so they were generally left closed all winter. Stop-logs were also very difficult to adjust during the ice season, so the gates and stop-logs were left alone and the control dam operated as a weir during the winter. As a result the reservoir level behind the original project fluctuated with discharge.

In April 1971, three gates, two piers and the adjoining overhead service deck were removed from Dam 1 at the direction of the Idaho Department of Water Resources. The remaining gates were opened, and flow was allowed to pass uncontrolled through the structure. However, the power dam (Dam 2) was still operational and was used periodically to produce power when flows were high enough. At least six additional gates and the adjoining piers were removed from Dam 1 on advanced warning of, or as a result of, the Teton Dam break in June 1976. Sections of the concrete gate sill were also damaged during the Teton Flood, resulting in a further lowering of the reservoir level.

The remains of the original power project were removed and replaced by the present structures in 1982 . Flow over Dam 1 is now controlled by two 10 -ft-high by 40-ft-wide bascule gates with a crest elevation of 4736.0 $\mathrm{ft}$ IFD. Dam 2 consists of a power plant, two free overflow spillways with a combined width of about 165 $\mathrm{ft}$, and an $11-\mathrm{ft}$-high by $40-\mathrm{ft}$-wide bascule gate. The crest elevation of the spillways and gates is $4736.0 \mathrm{ft}$ IFD. A stilling well and automatic controls are used to adjust the 
gates at Dam 1 so that the reservoir level is maintained at $4736.0 \mathrm{ft}$ IFD for a wide range of river discharges. The design flow through the new turbines is $6000 \mathrm{ft}^{3} / \mathrm{sec}$.

Because of the uncertainty about the datum for the original project and changes in gate operations, many possible reservoir level control elevations had to be considered in order to estimate water levels during the three periods of the Upper Power Project. Table A1 lists 10 possible scenarios and the resulting control elevations. For the interim period the gate sill of the original dam was chosen as the structural feature that probably controlled the stage. The elevations vary over a $9.9 \mathrm{ft}$ range from the present dam (scenario l) to the lowest sill elevation (scenario 4). For this study, three of the 10 scenarios were evaluated for open-water and ice-covered hydraulic conditions: the present dam (scenario 1) and the elevation minimums for the original project (scenario 7) and the interim period (scenario 4). The minimum reservoir elevation of the original dam was chosen because it represents the greatest difference between the original and present reservoir elevations. The remaining seven scenarios were eliminated because their reservoir levels fell within the extremes.

\section{Appendix Table A1. Possible reservoir control elevations at the Upper Power Project.}

\begin{tabular}{|c|c|c|c|}
\hline Scenario & $\begin{array}{l}\text { Historical } \\
\text { period }\end{array}$ & Description & $\begin{array}{l}\text { Reservoir } \\
\text { elevation } \\
\text { (IFD) }\end{array}$ \\
\hline 1 & $\begin{array}{l}\text { Present dam } \\
(1982-)\end{array}$ & Water level held steady & $4736.0^{*}$ \\
\hline 2 & $\begin{array}{l}\text { Original dam } \\
\text { nonoperational } \\
(1971-1982)\end{array}$ & $\begin{array}{l}\text { Water flowing over original } \\
\text { dam sill, assuming sill built } \\
\text { at } 4726.1 \text { PDD }\end{array}$ & $4727.4^{\dagger}$ \\
\hline 3 & $\begin{array}{l}\text { Original dam } \\
\text { nonoperational } \\
(1971-1982)\end{array}$ & $\begin{array}{l}\text { Water flowing over original } \\
\text { dam sill, assuming sill built } \\
\text { at } 4726.1 \text { NGVD }\end{array}$ & $4726.8^{\dagger}$ \\
\hline 4. & $\begin{array}{l}\text { Original dam } \\
\text { nonoperational } \\
(1971-1982)\end{array}$ & $\begin{array}{l}\text { Water flowing over original } \\
\text { dam sill, assuming sill built } \\
\text { at } 4726.1 \text { IFD }\end{array}$ & $4726.1^{\dagger}$ \\
\hline 5 & $\begin{array}{c}\text { Original dam } \\
(1928-1971) \\
.\end{array}$ & $\begin{array}{l}\text { Water level held steady, } \\
\text { assuming top of gate built } \\
\text { at } 4732.4 \text { PDD }\end{array}$ & $4733.7^{*}$ \\
\hline 6 & $\begin{array}{l}\text { Original dam } \\
(1928-1971)\end{array}$ & $\begin{array}{l}\text { Water level held steady, } \\
\text { assuming top of gate built } \\
\text { at } 4732.4 \text { NGVD }\end{array}$ & $4733.1^{*}$ \\
\hline 7 & $\begin{array}{l}\text { Original dam } \\
(1928-1971)\end{array}$ & $\begin{array}{l}\text { Water level held steady, } \\
\text { assuming top of gate built } \\
\text { at } 4732.4 \text { IFD }\end{array}$ & $4732.4^{*}$ \\
\hline 8 & $\begin{array}{l}\text { Original dam } \\
(1928-1971)\end{array}$ & $\begin{array}{l}\text { Water flowing over top of } \\
\text { gate, assuming top of gate } \\
\text { at } 4732.4 \text { PDD }\end{array}$ & $4733.7^{* *}$ \\
\hline 9 & $\begin{array}{l}\text { Original dam } \\
(1928-1971)\end{array}$ & $\begin{array}{l}\text { Water flowing over top of } \\
\text { gate, assuming top of gate } \\
\text { at } 4732.4 \text { NGVD }\end{array}$ & $4732.4^{* *}$ \\
\hline 10 & $\begin{array}{l}\text { Original dam } \\
\text { (1928-1971) }\end{array}$ & $\begin{array}{l}\text { Water flowing over top of } \\
\text { gate, assuming top of gate } \\
\text { at } 4732.4 \text { IFD }\end{array}$ & $4732.4^{* *}$ \\
\hline
\end{tabular}

\footnotetext{
* Reservoir elevation held steady through gate operations.

$\dagger_{* *}$ Reservoir elevation based on discharge over broad crested weir.

Reservoir elevation based on discharge over a series of sharp crested weirs.
} 


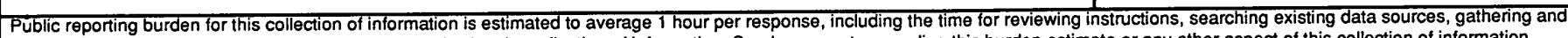
maintaining the data needed, and completing and reviewing the collection of information. Send comments regarding this burden estimate or any other aspect of this collection of information, including suggestion for reducing this burden, to Washington Headquarters Services, Directorate for Information Operations and Reports, 1215 Jefferson Davis Highway, Suite 1204, Arlington, VA 22202-4302, and to the Office of Management and Budget, Paperwork Reduction Project (0704-0188). Washington, DC 20503.

\begin{tabular}{|l|l|l|}
\hline 1. AGENCY USE ONLY (Leave blank) & 2. REPORT DATE REPORT TYPE AND DATES COVERED \\
\hline
\end{tabular}

\begin{tabular}{l|r} 
4. TITLE AND SUBTITLE & December \\
Ice Jam Analysis at Idaho Falls, Snake River, Idaho
\end{tabular}

\section{AUTHORS}

USAED, Walla Walla

Work Order E85860071

Jon E. Zufelt, Jeff A. Earickson and Lester Cunningham

7. PERFORMING ORGANIZATION NAME(S) AND ADDRESS(ES)

U.S. Army Cold Regions Research and Engineering Laboratory

72 Lyme Road

Hanover, New Hampshire 03755-1290

9. SPONSORING/MONITORING AGENCY NAME(S) AND ADDRESS(ES)

10. SPONSORING/MONITORING AGENCY REPORT NUMBER

U.S. Army Engineer Division, Walla Walla

Walla Walla, Washington 99362

11. SUPPLEMENTARY NOTES

12a. DISTRIBUTION/AVAILABILITY STATEMENT

12b. DISTRIBUTION CODE

Approved for public release; distribution is unlimited.

Available from NTIS, Springfield, Virginia 22161

13. ABSTRACT (Maximum 200 words)

The cause of ice jams on a reach of the Snake River upstream of the City of Idaho Falls, Idaho, was investigated. The relationship between ice jam flooding in a residential area developed in the mid-1970s and the reconstruction of a hydroelectric facility downstream was determined. Different configurations of the hydroelectric facility (new facility, old facility, and interim period) under open water and ice-covered conditions were accomplished using the U.S. Army Corps of Engineers HEC-2 backwater profile computer code with its ice cover option. Recommendations for ice jam flood control were made and actions were taken by the City of Idaho Falls.

14. SUBJECT TERMS

Frazil ice Hydraulic models
Ice control structures Ice jam flooding
17. SECURITY CLASSIFICATION OF REPORT

UNCLASSIFIED

18. SECURITY CLASSIFICATION
OF THIS PAGE
UNCLASSIFIED

UNCLASSIFIED

19. SECURITY CLASSIFICATION
OF ABSTRACT
UNCLASSIFIED

UNCLASSIFIED
8. PERFORMING ORGANIZATION

Special Report 90-43
15. NUMBER OF PAGES

16. PRICE CODE

20. LIMITATION OF ABSTRACT

UL 